\title{
PHYLOGENETIC CHARACTERIZATION OF VELOGENIC NEWCASTLE DISEASE VIRUSES ISOLATED FROM FIELD OUTBREAKS AMONG VACCINATED BROILER CHICKENS IN UPPER EGYPT
}

\author{
SERAGELDEEN SULTAN*; NABILA OSMAN**; AHMED I. AHMED ${ }^{* *}$; RAGAB S. IBRAHIM ${ }^{* * *}$ \\ and MAHMOUD SABRA** \\ * Department of Microbiology (Virology), Faculty of Veterinary Medicine, South Valley University, Qena 83523, Egypt \\ ** Department of Poultry Diseases, Faculty of Veterinary Medicine, South Valley University, Qena 83523, Egypt \\ ${ }^{* * * *}$ Department of Poultry Diseases, Faculty of Veterinary Medicine, Assiut University, Assiut 71515, Egypt
}

E-mail: seaas@1ycos.com.

Assiut University Email: www.aun.edu.eg

\section{ABSTRACT}

Received at: 30/3/2015

Accepted: 6/5/2015
A total of 42 Newcastle disease virus (NDV) strains were isolated from clinical samples obtained from chickens during field outbreaks among vaccinated broiler chicken's farms in the Upper Egypt in 2011 - 2012. The samples were inoculated into embrayonated chicken eggs and the positive samples for NDV were detected by hemagglutinination (HA) and confirmed by hemagglutination inhibition (HI) tests and reverse transcriptation polymerase chain reaction (RT-PCR). The pathogenicity of the isolates was estimated biologically by intracerebral pathogenicity index (ICPI) test and genetically by sequencing the partial fusion (F) genes. The ICPI indicated that 40 isolates were $>1.5$, which characterized velogenic strains, the remaining was mesogenic (ICPI = 1.4). The sequencing analysis of the nucleotides and deduced amino acids, 8 isolates representing the isolates from different localities, revealed that these isolates possess the amino acids motif $112-\mathrm{R}-\mathrm{R}-\mathrm{Q}-\mathrm{K}-\mathrm{R}-\mathrm{F}-117$ of the velogenic nature and a diversity of $19-22$ and $19-21 \%$ in nucleotides and amino acids, respectively, from vaccine strains (LaSota, B1, Ulster/67 and I-2) and Texas/GB. Interesting, that these isolates clustered into two subgroups related to the isolates from Jordan, Israel (2011) and China but were distant from vaccine, Egyptian (2005, 2006 and 2010), Sudan, Saudi Arabia and Israel (2003) strains by phylogenetic analysis. In conclusion, a velogenic NDV prove to circulate among chickens in southern of Egypt although intensive vaccination programs were conducted. These isolates were genetically away from the vaccine strains and virulent to chickens. The necessity needs to continuously monitor the virus and evaluate the vaccination programs efficiency.

Keywords: NDV, RT-PCR, phylogenetic analysis, outbreaks, vaccinated chickens

\section{INTRODUCTION}

Newcastle disease (ND) is one of the most economically important and prevalent poultry diseases around the world including Egypt. ND can be divided into five pathotypes based on severity of the disease in chickens. These are viscerotropic velogenic, neurotropic velogenic, mesogenic, lentogenic or respiratory and asymptomatic enteric type (Alexander, 1997). ND virus (NDV), a member of the avian paramyxovirus serotype 1 (APMV-1), belongs to the genus Avulavirus within the Paramyxoviridae family and is the causative agent of ND (Mayo, 2002). It is enveloped, negative-sense, single stranded RNA and its genome approximately 15.2 $\mathrm{Kb}$ in length which contains six genes in the order of 5'- NP - P - M - F - HN - L 3', coding nucleocapsid (NP), phosphoprotein (P), matrix (M), fusion $(\mathrm{F})$, haemagglutinin- neuraminidase $(\mathrm{HN})$ and a large polymerase protein (L). In additional to these proteins, $\mathrm{V}$ and $\mathrm{W}$ are generated by an RNA editing event that occurs during the transcription of the $\mathrm{P}$ gene (Steward et al., 1993). Various methods have been introduced for grouping and analysis of NDV including differences in pathogenicity (Alexander, 1997), antigenicity (Alexander et al., 1987; 1997) and genomes (Liu et al., 2003; Wehmann et al., 2003a; 2003b; De Leeuw et al., 2005). Several epidemiological studies of NDV have been carried out worldwide using molecular based methods (Aldous et al., 2003; Abolnik et al., 2004; Lee et al., 2004; Liu et al., 2007; Bogoyavlenskiy et al., 2009, Umali et al., 2013).

The molecular pathogenicity determinant of NDV is the F protein cleavage site (FPCS) sequence. The F0 protein must be processed into the disulphide-linked $\mathrm{F} 1$ and $\mathrm{F} 2$ peptides to penetrate and induce the fusion 
of the viral envelope with the cell membrane (Glickman, et al., 1988; Le et al., 1988). Velogenic and mesogenic strains contain multi basic amino acid residues at the site $(112 \mathrm{R} / \mathrm{K}-\mathrm{R}-\mathrm{Q}-\mathrm{R} / \mathrm{K}-\mathrm{R}-\mathrm{F}$ 117), which presents the F0 protein to cellular proteases found in a wide variety of tissues. On the other hand, lentogenic strains contain a few basic amino acid residues at the FPCS (112 G/E - K/R - Q -G/E - R- L 117) which limits F0 utility to trypsinlike proteases only (Gotoh, et al., 1992; Ogasawara, et al., 1992; Panda et al., 2004). Molecular typing of the cleavage site by DNA sequencing have been used in pathotypes prediction and phylogenetic studies to determine the evolutionary relationship of NDV isolates (Westover, and Hughes, 2001, Mase et al., 2002; Pedersen et al., 2004; Mohamed et al., 2011).

Although NDV has been detected in Egypt since 1948 (Daubney and Mansy, 1948), a limited molecular epidemiological data are available regarding the genotypes of ND have caused outbreaks among vaccinated poultry farms. Knowing the molecular characteristics of NDV strains affecting commercial poultry in spite of the application of intensive vaccination regimes might give important insights on the possible origins and genetic nature of these viruses. Also, this may help in formulating more effective ND prevention and control strategies.

A little studies have been performed investigating the classification of NDVs in the sub-genotype level and clarified the epidemiological relation of Egyptian NDVs with other in the same continent or parts of the world, which may help further elucidate the global and transcontinental dynamics of transmission and spread of this disease. Therefore, in the present study, NDVs from different geographical regions in the South of Egypt were isolated during outbreaks among vaccinated chickens in 2011-2012. The molecular and biological characterization of these isolates were investigated. The obtained sequenced data was compared with NDV strains isolated from the Lower Egypt, Middle East, Israel and China as well as vaccine strains and a novel NDV strain Texas/GB isolated in 1948 from chicken in USA.

\section{MATERIAL and METHODS}

\section{Sample collection and virus isolation}

A total of 108 samples were collected from broiler chicken farms at different localities (Sohag $(n=52)$, Qena $(n=48)$ and Luxor $(n=8))$ with case history of high mortality in spite of intensive vaccination programs against NDV in Upper Egypt during 2011 2012. The organs (proventriculus, liver, trachea, spleen, brain, lung, intestine and cecal tonsils) were collected from diseased birds with respiratory, nervous manifestations and diarrhea during postmortem examination (PM) (Table 1). All theses samples were transferred on ice to the laboratory,
Faculty of Veterinary Medicine, South Valley University, where virus isolation and characterization were performed. The data concerning the type of birds, system of farms, geographical area, type of samples, vaccination history, flock capacity, mortality rate, clinical signs and PM lesions were shown in table 1 .

The virus isolation was carried out through inoculation of 10 day old embryonated chicken eggs (ECE) via the allantoic cavity. The inoculated eggs were incubated at $37^{\circ} \mathrm{C}$ for 5-7 days with daily observing of the embryo viability. The allantoic fluid (AF) was harvested and examined for virus hemagglutination using the hemagglutination assay (HA), samples that show HA activities were subjected to hemagglutination inhibition (HI) test using an NDV specific antiserum (OIE, 2012). The AFs that exhibited HA activities were divided into aliquots and stored at $-80^{\circ} \mathrm{C}$ for further molecular and biological characterization.

\section{Pathogenicity test}

The pathogenic evaluation of the isolates was carried out using intracerebral pathogenicity index (ICPI) in 1-day-old chicks hatched from NDV antibody-free ECEs as previously described (Nabila et al., 2014). Briefly, a day-old chicks were inoculated intracerebrally with $0.05 \mathrm{ml}$ of a 1:10 dilution of AF has HA titer equal to or higher than 16. Chicks were kept under observation every $24 \mathrm{hrs}$ for a period of 8-days and apparent clinical signs on the chicks was scored as normal (0), sick or paralyzed (1) and dead (2). Total scores were determined and the mean daily score was calculated to obtain the ICPI (Alexander and Swayne, 1998).

\section{RNA extraction and OneStep reverse transcription polymerase chain reaction (RT- PCR)}

The viral RNA was extracted from the AFs using QIAamp Viral RNA Mini Kit (QIAGEN INC., Valencia, CA, USA ${ }^{\circledR}$ ) following the manufacturer's instructions. The extracted RNA was subjected to RT-PCR using two primers according to Lee et al. (2004). the forward primer (M1055); 5'-GCT GAT CAT GAG GTT ACC TC-' 3 and the reverse primer (F508); 5'-AGT CGG AGG ATG TTG GCA GC-3' to amplify a $695 \mathrm{bp}$ fragment spanning the regions between nucleotide position 508 of the $F$ protein and nucleotide position 1055 of the matrix protein, which includes the FPCS.

The RT-PCR reaction was carried out using QIAGEN OneStep RT-PCR kit (QIAGEN INC., Valencia, CA, $\left.\mathrm{USA}^{\circledR}\right)$. The reaction mixture was conducted in a final volume of $25 \mu \mathrm{l} ; 5 \times$ reaction buffer $5 \mu \mathrm{L}, 10 \mathrm{mM}$ dNTPs $1 \mu \mathrm{l}, 1.5 \mu \mathrm{l}(10 \mu \mathrm{M})$ of each primer (M1055 and F508), $1 \mu$ l of Qiagen one step RT-PCR enzyme mix, $5 \mu$ l of extracted RNA and $10 \mu$ l RNase-free water. The RT-PCR reaction was conducted in a 
thermalcycler (A200 Gradient, LongGene, Japan). Positive controls were prepared using RNA from live LaSsota vaccine commercially available, while the negative control was prepared using nuclease free water.

The RT-PCR conditions were as follows: one cycle of initial RT at $50^{\circ} \mathrm{C} / 30 \mathrm{~min}$, one cycle of initial denaturation at $95^{\circ} \mathrm{C} / 15 \mathrm{~min}$, followed by 30 cycles of denaturation at $94^{\circ} \mathrm{C} / 30 \mathrm{sec}$, annealing at $55^{\circ} \mathrm{C} / 30$ sec and extension at $72^{\circ} \mathrm{C} / 1 \mathrm{~min}$. One cycle of final $72^{\circ} \mathrm{C} / 10 \mathrm{~min}$ allowed for additional extension time. The PCR products were separated by gel electrophoresis using a $1 \% \mathrm{w} / \mathrm{v}$ agarose gel stained with ethidium bromide $(0.5 \mu \mathrm{g} / \mathrm{ml})$ and visualized under ultraviolet illumination (Vilber LOUR Mat, France) and photographed using gel documentation system (Micro-DOC, Cleaver scientific, UK) with canon digital camera.

\section{Sequencing and phylogenetic analysis}

The amplified PCR products were purified using the QIAquick PCR purification kits (QIAGEN, USA) according to the manufacturer's instructions. Then the purified products were sequenced by an Applied Biosystems prism 310 (Molecular biology unit, Assuit University) automated DNA Sequencer using a BigDye terminator v.3.1 cycle sequencing kit (ABI, Foster city, CA, USA). The nucleotide sequence analysis and prediction of deuced amino acid sequences for the partial $\mathrm{F}$ genes were conducted with CLUSTAL W, Ver. 1.4 using BioEdit package, Ver. 7.2 software. The phylogenetic tree was constructed using the Maximum Composite Likelihood method supported by 1000 bootstrap replications (Saitou and Nei 1987) and Mega 5.0 software (Tamura et al., 2011). The nucleotides and deduced amino acids of the partial $\mathrm{F}$ gene sequences of the present isolates were compared with those sequences of the NDV isolated from Middle East (Egypt (2005, 2006, and 2012), Sudan, Jordan and Saudi Arabia), vaccine strains, Texas-GB, China and Israel selected by BLAST homology. The sequences obtained in this study were deposited in GenBank under accession numbers as shown in table 2 .

\section{RESULTS}

\section{The isolation and characterization of NDV from} clinical samples

Out of the 108 examined clinical samples 42 AFs were HA positive through virus propagation in the ECEs. The positive AFs were confirmed as NDVs by HI test using specific NDV antiserum. The pathogenicity of the NDV isolates in this study was estimated in 1-day-old chicks by ICPI test. The results revealed that 40 isolates had ICPI greater than 1.5 therefore were velogenic strains while 2 isolates had ICPI equal to 1.4 and 1.46 which corresponding to the mesogenic strains. The results of one step RT-
PCR of the extracted RNA from the positive AFs using primers targeting the $695 \mathrm{bp}$ fragment between nucleotides 1055 of the $M$ gene upstream and nucleotides 508 of the F gene downstream the FPCS indicated that all 42 AFs were positive for the presence of the amplified fragment as shown in Fig 1. Eight out of the $42 \mathrm{NDV}$ positive isolates were selected from different localities (5/28 Sohag, 2/12 Qena and 1/2 Luxor) based on the number of isolates obtained from this area, at different time (2011 (4/42) and (4/42) 2012), age, flock capacity, clinical signs, PM lesions and mortality rates (Tables 1 and 2). Also, the biological features of this 8 isolates including HA, HI and ICPI were determined as shown in table 2 . The isolates were subjected to further molecular characterization by sequencing the obtained fragment (695 bp). The deduced amino acid sequence of the F proteins cleavage site of all of these velogenic strains was the ${ }^{112} \mathrm{R}-\mathrm{R}-\mathrm{Q}-\mathrm{K}-\mathrm{R}-\mathrm{F}^{117}$ motifs which characteristics the virulent NDV strains (Table 2 and Fig. 2).

Comparative analysis of nucleotide and deduced amino acid sequences of the partial $F$ genes

The nucleotide similarities of the 420 nucleotides fragment, between the start codon and the cleavage site of the $\mathrm{F}$ gene, and predicted amino acid sequences of 139 residues of the $8 \mathrm{NDV}$ isolates were compared with the corresponding sequences of the LaSota, the frequently used vaccine strain in Egypt, Texas/GB and Egyptian isolates (2006 and 2012) from northern Egypt (Table 3). The identities among the obtained isolates showed $98-100 \%$ and $97-100 \%$ in nucleotides and amino acids, respectively (Table 4). In the other hand, the 8 isolates showed a divergent of $20-22 \%$ (identities $78-80 \%$ ) for the nucleotide sequence and $21 \%$ (identity $79 \%$ ) for amino acid sequence in compare to LaSota strain. These dissimilarities to Texas/GB and Egyptian NDV/chicken/3/2006 (abbreviated to 3/2006) were $19-22 \%, 19-20 \%$ for nucleotide sequence and $16-18 \%$, $14-16 \%$ for amino acid sequence, respectively. The present isolates and Egyptian NDV/chicken/ VRLCU138/12 (abbreviated to VRLCU138/12), isolated in northern Egypt in 2012, showed identities of $99 \%$ and $99-100 \%$ for nucleotides and amino acids, respectively (Table 4).

The analysis of 139 deduced amino acids of the $F$ gene sequences of the 8 isolates revealed that they had the amino acid motifs ${ }^{112} \mathrm{R}-\mathrm{R}-\mathrm{Q}-\mathrm{K}^{116}$ at the Cterminus of the $\mathrm{F} 2$ proteins and phenylalanine $(\mathrm{F})$ at amino acid residue 117 (Fig 2 and Table 2). Among the 8 strains unique amino $\operatorname{acid}(\mathrm{s})$ was detected such as NDV/CK/EG/129/12 had proline (P) instead of leucine (L) at position 13 (Fig 2), due to a substitution of nucleotide cytosine instead of thiamine at position 38 as transition mutation and isoleucine (I) instead of valine at position 43 (Fig 2) as a result of substitution of nucleotide adenine instead of guanine at position 130 as transition mutation. Also, the isolate 
NDV/CK/EG/101/12 had a unique amino acid (L) instead of serine (S) at position 54 (Fig 2) due to transition mutation of thiamine instead of cytosine at position 163.

\section{Phylogenetic analysis}

The phylogenetic tree based on sequence analysis of the first 420 nucleotides of the $F$ gene open reading frame of the $8 \mathrm{NDV}$ strains was constructed with the represented sequences obtained from the Genbank (Table 3) of vaccine strains (LaSota, B1, I-2 and Ulster 67), Middle East, Egyptian (2005, 2006, 2010 and 2012), Israel (2003 and 2011) and China (2003) as shown in Fig 3. Based on the topology of the tree the isolates have been located in a separated genotype far away from the vaccine strains and the novel NDV
Texas/GB. The isolates were clustered into two groups; one group contains NDV/CK/EG/83/11, NDV/CK/EG/13/11, NDV/CK/EG/146/12, NDV/ CK/EG /101 /12, NDV/CK/EG/135/12, NDV/CK/ EG/20/11 as one clade and NDV/CK/EG/129/12 as another clade which are closely related to the Egyptian isolate (NDV-EG-567F-2012) as shown in Fig 3. The second group contains NDV/CK/EG/67/11 that is located nearby NDV isolated from Israel 2011 (Chicken/Israel/555/2011). The 8 isolates were clustered together with isolates from Jordan, Israel and northern Egypt 2012 but were distant from those originated from China, Saudi Arabia and Sudan (Fig $3)$.

Table 1: The collecting data of some of the biologically and molecularly characterized NDV isolates from vaccinated chickens in Upper Egypt.

\begin{tabular}{|c|c|c|c|c|c|c|c|c|c|}
\hline ID & $\begin{array}{r}\text { Type of } \\
\text { Chicken } \\
\end{array}$ & $\begin{array}{l}\text { Age } \\
\text { (day) }\end{array}$ & $\begin{array}{c}\text { Farm } \\
\text { system }\end{array}$ & $\begin{array}{c}\text { Flock } \\
\text { capacity }\end{array}$ & Year & $\begin{array}{l}\text { Type of } \\
\text { sample } \\
\end{array}$ & $\begin{array}{c}\text { Mortality } \\
\text { rate }(\%)\end{array}$ & Clinical signs & PM lesion \\
\hline $\mathrm{NDV} / \mathrm{EG} / \mathrm{CK} / 13^{\mathrm{a}} / 11^{\mathrm{b}}$ & Broiler & 30 & $\begin{array}{l}\text { Deep } \\
\text { litter }\end{array}$ & 2500 & 2011 & Organs & $35-80$ & $\begin{array}{l}\text { Respiratory signs } \\
\text { Greenish diarrhea }\end{array}$ & \multirow{4}{*}{$\begin{array}{c}\text { Button like ulcers } \\
\text { in small intestines } \\
\mathrm{Hg} \text { in cecal tonsils } \\
\mathrm{Hg} \text { tracheitis } \\
\text { Congested lung } \\
\text { Petechial Hg spots } \\
\text { on proventricular } \\
\text { glands }\end{array}$} \\
\hline NDV/EG/CK/20/11 & Broiler & 36 & $\begin{array}{l}\text { Deep } \\
\text { litter }\end{array}$ & 4500 & 2011 & Organs & $>90$ & $\begin{array}{l}\text { Respiratory signs } \\
\text { Greenish diarrhea }\end{array}$ & \\
\hline NDV/EG/CK/67/11 & Broiler & 32 & $\begin{array}{l}\text { Deep } \\
\text { litter }\end{array}$ & 2800 & 2011 & Organs & $>90$ & $\begin{array}{l}\text { Respiratory signs } \\
\text { Greenish diarrhea }\end{array}$ & \\
\hline NDV/EG/CK/83/11 & Broiler & 55 & $\begin{array}{l}\text { Deep } \\
\text { litter }\end{array}$ & 1500 & 2011 & Organs & $40-55$ & $\begin{array}{c}\text { Drowsiness } \\
\text { Respiratory signs } \\
\text { Greenish diarrhea } \\
\end{array}$ & \\
\hline NDV/EG/CK/101/12 & Broiler & 39 & $\begin{array}{l}\text { Deep } \\
\text { litter }\end{array}$ & 2000 & 2012 & Organs & $40-55$ & $\begin{array}{c}\text { Nervous signs } \\
\text { Whitish watery } \\
\text { diarrhea }\end{array}$ & $\begin{array}{c}\text { As in }{ }^{\mathrm{c}} \\
\text { Congestion in the } \\
\text { brain }\end{array}$ \\
\hline NDV/EG/CK/129/12 & Broiler & 24 & $\begin{array}{l}\text { Deep } \\
\text { litter }\end{array}$ & 3200 & 2012 & Organs & $>90$ & $\begin{array}{l}\text { Respiratory signs } \\
\text { Greenish diarrhea }\end{array}$ & As in ${ }^{c}$ \\
\hline NDV/EG/CK/135/12 & Broiler & 36 & $\begin{array}{l}\text { Deep } \\
\text { litter }\end{array}$ & 4000 & 2012 & Organs & $>90$ & \multirow{2}{*}{$\begin{array}{c}\text { Drowsiness } \\
\text { Respiratory signs } \\
\text { Nervous signs }\end{array}$} & \multirow{2}{*}{$\begin{array}{c}\text { As in }{ }^{c} \\
\text { Congestion in the } \\
\text { brain }\end{array}$} \\
\hline NDV/EG/CK/146/12 & Broiler & 27 & $\begin{array}{l}\text { Deep } \\
\text { litter }\end{array}$ & 12000 & 2012 & Organs & $>90$ & & \\
\hline
\end{tabular}

$\mathrm{EG}=$ Egypt $\quad \mathrm{CK}=$ chicken

${ }^{a}$ The strain number

${ }^{b}$ The isolation year

c The same PM lesions as that was previously described above

Table 2: The hemagglutinating activity, pathogenicity properties and cleavage site motif of the selected NDV isolates from field outbreaks during $2011-2012$.

\begin{tabular}{|c|c|c|c|c|c|c|c|}
\hline ID & HA titer $^{\text {a }}$ & HI titer ${ }^{a}$ & ICPI value & $\mathrm{F}$ gene cleavage site & NDV Pathotype & Location & $\begin{array}{c}\text { Accession } \\
\text { numbers }\end{array}$ \\
\hline NDV/EG/CK/13/11 & 128 & 128 & 1.54 & ${ }^{112} \mathrm{R}-\mathrm{R}-\mathrm{Q}-\mathrm{K}-\mathrm{R}{ }^{116} \mathrm{~F}^{117}$ & Velogenic & Sohag & AB871426 \\
\hline NDV/EG/CK/20/11 & 128 & 512 & 1.8 & ${ }^{112} \mathrm{R}-\mathrm{R}-\mathrm{Q}-\mathrm{K}-\mathrm{R}^{116} \mathrm{~F}^{117}$ & Velogenic & Sohag & AB871425 \\
\hline NDV/EG/CK/67/11 & 128 & 256 & 1.96 & ${ }^{112} \mathrm{R}-\mathrm{R}-\mathrm{Q}-\mathrm{K}-\mathrm{R}^{116} \mathrm{~F}^{117}$ & Velogenic & Sohag & AB871428 \\
\hline NDV/EG/CK/83/11 & 512 & 128 & 2 & ${ }^{112} \mathrm{R}-\mathrm{R}-\mathrm{Q}-\mathrm{K}-\mathrm{R}^{116} \mathrm{~F}^{117}$ & Velogenic & Luxor & AB871422 \\
\hline NDV/EG/CK/101/12 & 64 & 256 & 1.53 & ${ }^{112} \mathrm{R}-\mathrm{R}-\mathrm{Q}-\mathrm{K}-\mathrm{R}^{116} \mathrm{~F}^{117}$ & Velogenic & Sohag & AB871427 \\
\hline NDV/EG/CK/129/12 & 64 & 128 & 1.99 & ${ }^{112} \mathrm{R}-\mathrm{R}-\mathrm{Q}-\mathrm{K}-\mathrm{R}^{116} \mathrm{~F}^{117}$ & Velogenic & Sohag & AB871423 \\
\hline NDV/EG/CK/135/12 & 128 & 2048 & 1.64 & ${ }^{112} \mathrm{R}-\mathrm{R}-\mathrm{Q}-\mathrm{K}-\mathrm{R}^{116} \mathrm{~F}^{117}$ & Velogenic & Qena & AB863742 \\
\hline NDV/EG/CK/146/12 & 64 & 2048 & 1.58 & ${ }^{112} \mathrm{R}-\mathrm{R}-\mathrm{Q}-\mathrm{K}-\mathrm{R}^{116} \mathrm{~F}^{117}$ & Velogenic & Qena & AB871424 \\
\hline
\end{tabular}

${ }^{a}$ The HA and HI titers expressed as the reciprocal of the highest dilution given a positive result 
Assiut Vet. Med. J. Vol. 61 No. 145 April 2015

Table 3: The data about the isolates obtained form Gen Bank for alignment and phylogenetic analysis.

\begin{tabular}{ccccc}
\hline Strain & Country & Host & $\begin{array}{c}\text { Accession } \\
\text { numbers }\end{array}$ & Genotype \\
\hline Ulster/67 N. Ireland & N. Ireland & Chicken & AY562991 & I \\
\hline Strain I-2 & Australia & Chicken & AY935499 & I \\
\hline LaSota & China & Vaccine & DQ195265 & II \\
\hline Strain B1 & USA & Vaccine & AF309418 & II \\
\hline Texas/GB/1948 & USA & Chicken & GU978777 & II \\
\hline NDV/Chicken/Egypt/1/2005 & Egypt & Chicken & FJ939313 & $-{ }^{\text {a }}$ \\
\hline NDV/Chicken/2/2006 & Egypt & Chicken & FJ969393 & II \\
\hline NDV/Chicken/3/2006 & Egypt & Chicken & FJ969394 & II \\
\hline NDV/Chicken/4/2006 & Egypt & Chicken & FJ969395 & II \\
\hline NDV/Ostrich/Ismailia/2010 & Egypt & Ostrich & JN193503 & II \\
\hline Chicken/China/YMF3/2003 & China & Chicken & AY390313 & VII \\
\hline NDV/chicken/VRLCU138//2012 & Egypt & Chicken & JX885868 & VII \\
\hline NDV-EG-567F-2012 & Egypt & Chicken & JX647839 & VIId \\
\hline chicken/Israel/998/2011 & Israel & Chicken & KC484655 & VII \\
\hline Chicken/555/2011 & Israel & Chicken & JN849577 & - \\
\hline Chicken/Israel/1258/2003 & Israel & Chicken & JF795623 & - \\
\hline apmv1/chicken/Jordan/2011 & Jordan & Chicken & JQ176687 & VIId \\
\hline chicken/Saudi Arabia/AV 237/2000 & Saudi Arabia & Chicken & AY135754 & - \\
\hline chicken/Sudan/BSDCK72176/1972 & Sudan & Chicken & AY135753 & - \\
\hline
\end{tabular}

${ }^{\mathrm{a}}$ The genotype not determined

Table 4: The identity of nucleotides and deduced amino acids of the $\mathrm{F}$ gene sequences ${ }^{\mathrm{a}}$ of the isolated NDVs in compared to LaSota, Egyptian (2006 and 2012) and Texas/GB strains.

\begin{tabular}{|c|c|c|c|c|c|c|c|c|c|c|c|c|}
\hline Strain $^{b}$ & LaSota & $135 / 12$ & $83 / 11$ & $67 / 11$ & $101 / 12$ & $13 / 11$ & $20 / 11$ & $146 / 12$ & $129 / 12$ & VRLCU138/12 & $3 / 2006$ & Texas/GB \\
\hline LaSota & & 80 & 79 & 79 & 79 & 79 & 79 & 80 & 78 & 80 & 82 & 95 \\
\hline $135 / 12$ & 79 & & 99 & 98 & 98 & 98 & 98 & 100 & 98 & 99 & 84 & 81 \\
\hline $83 / 11$ & 79 & 100 & & 99 & 99 & 99 & 99 & 99 & 98 & 99 & 84 & 81 \\
\hline $67 / 11$ & 79 & 100 & 100 & & 99 & 99 & 99 & 98 & 99 & 99 & 84 & 80 \\
\hline $101 / 12$ & 79 & 99 & 99 & 99 & & 99 & 99 & 98 & 99 & 99 & 84 & 80 \\
\hline $13 / 11$ & 79 & 100 & 100 & 100 & 99 & & 100 & 98 & 99 & 99 & 84 & 80 \\
\hline $20 / 11$ & 79 & 100 & 100 & 100 & 99 & 100 & & 98 & 99 & 99 & 84 & 80 \\
\hline $146 / 12$ & 79 & 100 & 100 & 100 & 99 & 100 & 100 & & 98 & 99 & 84 & 81 \\
\hline $129 / 12$ & 79 & 98 & 98 & 98 & 97 & 98 & 98 & 98 & & 99 & 84 & 78 \\
\hline VRLCU138/12 & 79 & 100 & 100 & 100 & 99 & 100 & 100 & 100 & 98 & & 84 & 81 \\
\hline $3 / 2006$ & 79 & 86 & 86 & 86 & 85 & 86 & 86 & 86 & 84 & 86 & & 83 \\
\hline Texas/GB & 94 & 81 & 81 & 81 & 80 & 81 & 81 & 81 & 80 & 81 & 82 & \\
\hline
\end{tabular}

${ }^{\mathrm{a}}$ The identity of nucleotides (upper half) and deduced amino acids (lower bold half)

b The isolates' names were abbreviated by adding only the strain number and isolation year. The isolates obtained in this study are in bold

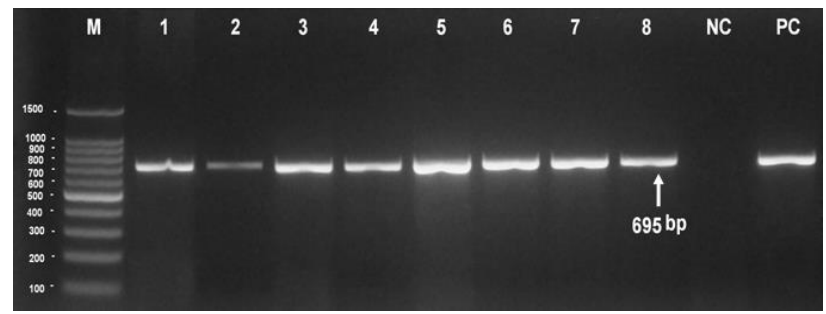

Fig. 1: The RT-PCR products (695bp) of NDV RNA using two primers targeting nucleotides 1055 of the M gene sequence upstream the $\mathrm{F}$ gene start codon and nucleotides 508 of the $\mathrm{F}$ gene sequence downstream the cleavage site in $1 \%$ agarose gel stained with ethidium bromide $(0.5 \mu \mathrm{g} / \mathrm{ml})$ after electrophoresis and photographed using gel documentation system (MicroDOC, Cleaver scientific, Ltd, UK) with Canon digital camera.

Lane M: 100 bp DNA ladder

Lanes $(1-8)$ : positive samples for NDV isolates

PC: positive control (live LaSota strain)

NC: negative control (RT-PCR master mix without template RNA) 


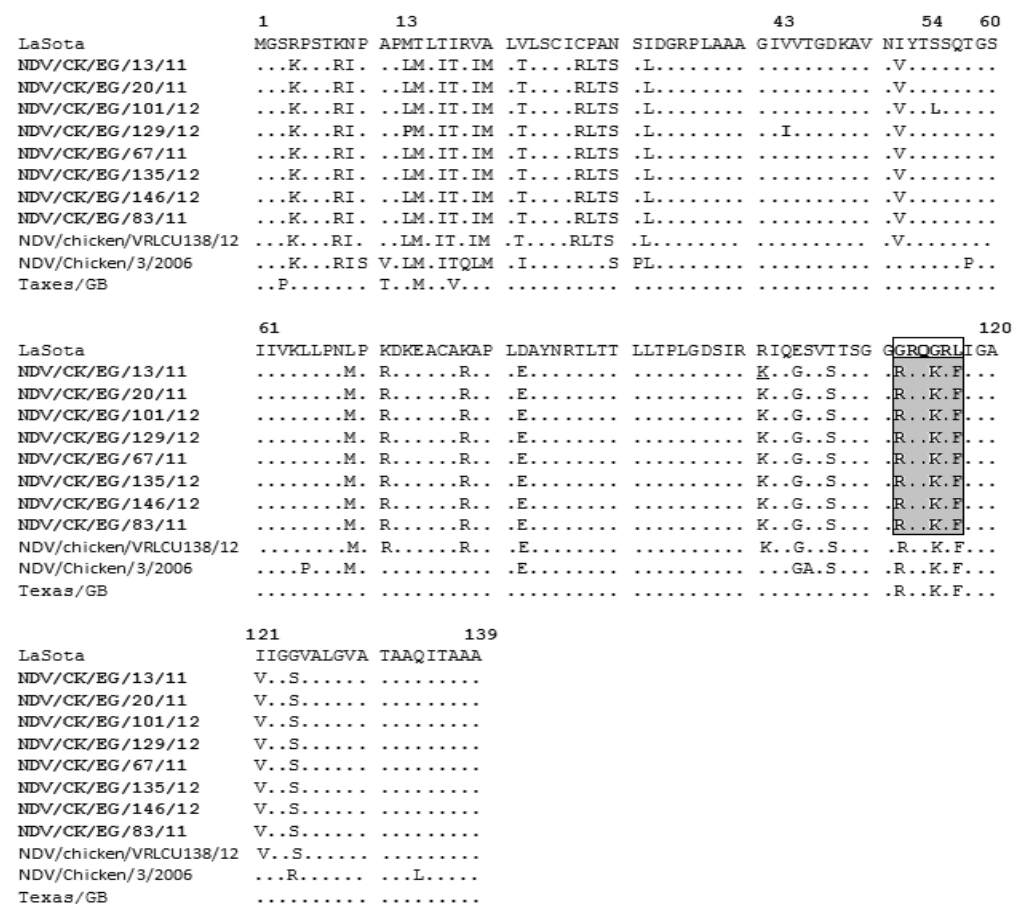

Fig. 2: Alignment of deduced amino acid sequences of the partial $F$ genes of NDV field isolates in compare to LaSota, Texas GB and Egyptian isolates in 2006 (NDV/Chicken/3/2006) and 2012 (NDV/chicken/VRLCU138/12). The identical amino acids are shown in dots while those are different either from LaSota or from each other indicated in letter. The position of unique amino acids for the present isolates (bold) as well as the start and the end of aligned amino acids are shown. The F protein cleavage site of the LaSota (open box) and those of the present isolates (shaded box) are indicated.

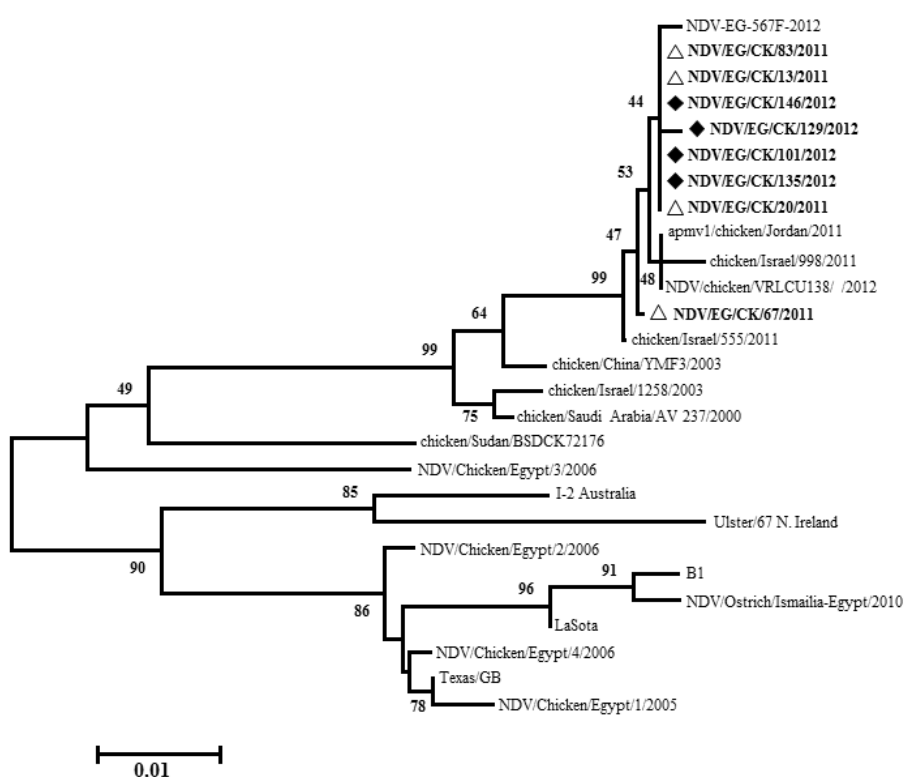

Fig. 3: Phylogenetic tree based on partial F gene nucleotide sequences ( $420 \mathrm{bp}$ ) of NDV isolates in the present study shown in bold (open triangle in 2011 and closed diamond in 2012) and the sequences of NDV isolated in Middle East (Egypt, Sudan, Saudi Arabia and Jordan), Israel, China and vaccine strains were obtained from Gen Bank (Table 3). The evolutionary history was inferred using the Neighbor-Joining method and the evolutionary distances were computed using the Maximum Composite Likelihood method. The numbers at each branch indicated bootstrap values $>40 \%$. All positions containing gap and missing data were removed. The phylogenetic analysis was performed in MEGA 5.0 software. The scale bar indicated 0.01 nucleotide substitutions per site. 


\section{DISCUSSION}

ND is one of the destructive viral diseases threaten the poultry industry. In the last decades the poultry industry speedy grow up in Upper Egypt as a source of the animal protein and income for farmers. Although NDV has been confirmed among chickens in Egypt since 1948 (Daubney and Mansy, 1948) the outbreaks caused by NDV infection among chickens' farms are occurring. In the previous study the endemic status, isolation and pathotyping of NDV among the backyard and broiler chickens in southern of Egypt was reported (Nabila et al., 2014).

In the present report the molecular characterization and phylogenetic relationship among the NDV isolates from vaccinated broiler chickens and NDV strains originated from different regions were investigated. These isolates were biologically virulent for chickens by ICPI test with indices from 1.4 to 2 these ICPI variations reported and used as a biological tool for NDV characterization (Cattoli et al., 2000; Capua et al., 2002; Ananth et al., 2008).

The RT-PCR amplification of the viral RNA genome fragment of the AFs showing HA and HI activities confirmed that the NDV are present in all 42 samples (Fig 2). The sequencing analysis of the $F$ gene is considered as rapid method for pathotyping of NDV and given invaluable data for the molecular epidemiology of the virus including its origin, spread and evolution (Aldous and Alexander, 2001). The sequence analysis revealed that the 8 isolates shared $78-81 \%$ and $79 \%$ identity in nucleotides and amino acids, respectively with LaSota strain (Table 4). The mismatching $(21 \%)$ between the isolates and LaSota may contributed to vaccination inefficiency and occurrence of NDV infection among vaccinated chickens. The cleavage of the precursor glycoprotein F0 into F1 and F2 proteins by cellular proteases is essential for virus virulence. Fig. 2 shows the alignment of the $\mathrm{F}$ protein cleavage site and those of the vaccine and other strains. A consensus amino acid motifs of ${ }^{112} \mathrm{R}-\mathrm{R}-\mathrm{Q}-\mathrm{K}-\mathrm{R}-\mathrm{F}^{117}$ is present in velogenic strains, while ${ }^{112}$ G/E-K/R-Q-G/E-R-L ${ }^{117}$ is characteristic for the low virulent strains ( $\mathrm{Li}$ et al., 2002; Panda et al., 2004). The presence of (F) amino acid residue at 117 position may be contributed to the nervous manifestations on birds (Kattenbelt et al., 2006). The genetic characterization of the NDV isolates in this study revealed that all $8 \mathrm{NDV}$ strains possess the amino acid sequence ${ }^{112} \mathrm{R}-\mathrm{R}-\mathrm{Q}-\mathrm{K}-\mathrm{R}-\mathrm{F}^{117}$ as velogenic strains (Table 2 and Fig 2). The genotype VII divided into 5 sub-lineages; VIIa isolates originated from Indonesia in 1988 and Europe in 1990, VIIb contained isolates from Europe, South Africa and Mozambique in the late1980 and 1990, VIIc composed isolates from Taiwan, Japan and China in 1984 and VIId isolates obtained from
Far East Asia (Taiwan, Japan, China and South Korea) in the middle 1990 and 2002. The amino acid residues lysine $(\mathrm{K})$, serine $(\mathrm{S})$ and isoleucine $(\mathrm{I})$ at positions 101, 107 and 118 are characteristic to genotypes VI and VII (Lee et al., 2004). The unique amino acids valine (V) instead of (I) at position 52 $\left({ }^{52} \mathrm{~V}^{52} \mathrm{I}\right)$ and arginine $(\mathrm{R})$ instead of $(\mathrm{K})$ at position 71 $\left({ }^{71} \mathrm{R} /{ }^{71} \mathrm{~K}\right)$ substitutions characteristic to sub-genotype VIId (Liu et al., 2003), all the sequenced 8 NDV strains in the present study had these amino acids as in Fig 2 which indicated that these isolates belongs to sub-genotype VIId. This genotype were responsible for ND outbreaks in goose flocks in southern China (Liu et al., 1999) although the goose is resistant to the most virulent strains of NDV for chickens (Alexander 1997).

The phylogenetic tree located the obtained isolates in a sub-lineage away from those isolated from Sudan and Saudi Arabia and close to isolates from Jordan and Israel (Fig 3) indicated the circulation of more than one sub-genotype in the Middle East although further large scale investigations are necessary. Also, the Egyptian isolates were located into three sublineages based on the time period where those in 2005 and some of 2006 were close to genotype II while the other 2006 isolates were cluster in sub-lineages distant from those in 2012 (Fig 3). This indicated continuous mutation among the NDV strains circulated in Egypt. The present data revealed that among the 8 isolates amino acid variations up to $3 \%$ were detected (Table 4) with unique amino acids characteristic to these isolates (Fig 2).

\section{CONCLUSION}

NDV isolates from vaccinated chicken in the South of Egypt were sequenced and analysed. The isolates are low similar with the LaSota vaccine strain and shows molecular markers of virulent NDV genotype VIId. The isolates were different from those isolated in Egypt 2005 and 2006 as well as Sudanic and Saudi Arabia isolates. Also, amino acid differences were observed among the isolates. This data may contributed to the understanding of the molecular epidemiology and improving the control measurement of NDV in Egypt.

\section{REFERENCES}

Abolnik, C.; Horner, R.F.; Bisschop, S.P.R.; Parker, M.E.; Romito, M. and Viljoen, G.J. (2004): A phylogenetic study of South African Newcastle disease virus strains isolated between 1990 and 2002 suggests epidemiological origins in the Far East. Archives of Virology, 149: 603-619. 
Aldous, E.W. and Alexander, D.J. (2001): Detection and differentiation of Newcastle disease virus (avian paramyxovirus type 1). Avian Pathology, 30: 117-128.

Aldous, E.W.; Mynn, J.K.; Banks, J. and Alexander, D.J. (2003): A molecular epidemiological study of avian paramyxovirus type 1 (Newcastle disease virus) isolates by phylogenetic analysis of a partial nucleotide sequence of the fusion protein gene Avian Pathology, 32 (3), 239-256.

Ananth, R.; Kirubaharan, J.J.; Priyadarshini, M.L.M. and Albert, A. (2008): Isolation of Newcastle Disease Viruses of High Virulence in Unvaccinated Healthy Village Chickens in South India. International Journal of Poultry Science, 7: 368-373.

Alexander, D.J. (1997): Newcastle disease and other avian paramyxoviridae infections. In B.W. Calnek, H.J. Barnes, C.W. Beard, L.R. McDougald and Y.M.Saif (Eds.), Diseases of poultry, $10^{\text {th }}$ ed. p 541- 569. Ames: Iowa State University Press.

Alexander, D.J and Swayne, D.E. (1998): Newcastle disease virus and other avian paramyxoviruses, In Swayne DE, Glisson JR, Jackwood MW, Pearson JE, Reed WM, editors. (ed), A laboratory manual for the isolation and identification of avian pathogens, vol 4 The American Association of Avian Pathologists, Kennett Square, PA p 156-163.

Alexander, D.J.; Manvell, R.J.; Kem, P.A.; Parsons, G.; Collins, M.S.; Brockman, S.; Russell, P.H. and Lister, S.A. (1987): Use of monoclonal antibodies in the characterization of avian paramyxovirus type 1 (Newcastle disease virus) isolates submitted to an international reference laboratory. Avian pathology, 16, 553-565.

Alexander, D.J.; Manvell, R.J.; Lowings, J.P.; Frost, K.M.; Collins, M.S., Russell, P.H. and Smith, J.E. (1997): Antigenic diversity and similarities detected in avian paramyxovirus type 1 (Newcastle disease virus) isolates using monoclonal antibodies. Avian Pathology, 26: 399-418.

Bogoyavlenskiy, A.; Berezin, V.; Prilipov, A.; Usachev, E.; Lyapina, O.; Korotetskiy, I.; Zaitceva, I.; Asanova, S.; Kydyrmanov, A.; Daulbaeva, K.; Shakhvorostova, L.; Sayatov, M. and King, D. (2009): Newcastle disease outbreaks in Kazakhstan and Kyrgyzstan during 1998, 2000, 2001, 2003, 2004, and 2005 were caused by viruses of the genotypes VIIb and VIId. Virus Genes, 39: 94-101.

Capua, I.; Dalla Pozza, M.; Mulinelli, F.; Marangon, S. and Terregino, C. (2002): Newcastle disease outbreaks in Italy during 2000. Veterinary Record, 150: 565-568.
Cattoli, G.; Manvell, R.J.; Tisato, E.; Banks, J. and Capua, I. (2000): Characterization of Newcastle disease viruses isolated in Italy in 2000. Avian Pathology, 30: 465-469.

De Leeuw, O.S.; Koch, G.; Hartog, L.; Ravenshorst, N. and Peeters, B.P. (2005): Virulence of Newcastle disease virus is determined by the cleavage site of the fusion protein and by both the stem region and globular head of the haemagglutinin-neuraminidase protein. Journal of General Virology 86: 1759-1769.

Daubney, R. and Mansy, W. (1948): The occurrence of Newcastle disease in Egypt. Journal of comparative pathology, 58: 189-196.

Glickman, R.L.; Syddall, R.J.; Iorio, R.M.; Sheehan, J.P. and Bratt, M.A. (1988): Quantitative basic residue requirement in the cleavage activation site of the fusion glycoprotein as a determinant of virulence for Newcastle disease virus. Journal of Virology, 62: 354-356

Gotoh, B.; Ohnishi, N.; Inocentio, M.; Esaki, E.; Nakayama, K.; Barr, P.J.; Thomas, G. and Nagai, Y. (1992): Mammalian subtilisinrelated proteinases in cleavage activation of the paramyxovirus fusion glycoprotein: superiority of furin/PACE to PC2 or PC1/PC3. Journal of Virology, 66: 6391- 6397.

Kattenbelt, J.A.; Stevens, M.P. and Gould, A.R. (2006): Sequence variation in the Newcastle disease virus genome, Virus Research, 116: 168-184.

Lee, Y.J.; Sung, H.W.; Choi, J.G.; Kim, J.H. and Song, C.S. (2004): Molecular epidemiology of Newcastle disease viruses isolated in South Korea using sequencing of the fusion protein cleavage site region and phylogenetic relationships. Avian Pathology, 33(5): 482491.

Le, L.; Brasseur, C.; Wemers, C.; Meulemans, G. and Burny, A. (1988): Fusion (F) protein gene of Newcastle disease virus: sequence and hydrophobicity comparative analysis between virulent and avirulent strains. Virus Genes 1: 333-350

Li, Y.; Collins, M.S.; Whitelam, G.C. and Alexander, D.J. (2002): Rapid pathotyping of Newcastle disease virus using a single-chain Fv displayed on phage against the $\mathrm{C}$-terminal end of the F2 polypeptide. Archives of virology, 147(10): 2025-2037.

Liu, X.F.; Wan, H.Q.; Ni, X.X.; Wu, Y.T. and Liu, W.B. (2003): Pathotypical and genotypical characterization of strains of Newcastle disease virus isolated from outbreaks in chickens and goose flocks in some regions of china during 1985 - 2001. Archives of Virology, 148, 1387-1403.

Liu, X.F.; Wu, Y.T.; Wen, Q.Y.; Dong, W.; Qu, G.R.; Peng, D.X. and Zhang, R.K. (1999): Newcastle disease isolates with pathogenicity 
of inducing clinical disease in the goose. Proceeding, 99 international conference and exhibition on veterinary poultry, Beijing, China, p 130-136.

Liu, H.; Wang, Z.; Wu, Y.; Zheng, D.; Sun, C.; Bi, D.; Zuo, Y. and Xu, T. (2007): Molecular epidemiological analysis of Newcastle disease virus isolated in China in 2005. Journal of Virological Methods, 140: 206-211.

Mase, M.; Imai, K.; Sanada, Y.; Sanada, N.; Yuasa, N.; Imada, T.; Tsukamoto, K. and Yamaguchi, S. (2002): Phylogenetic analysis of Newcastle disease virus genotypes isolated in Japan. Journal of Clinical Microbiology, 40: 38263830.

Mohamed, M.H.; Kumar, S.; Paldurai, A. and Samal, S.K. (2011): Sequence analysis of fusion protein gene of Newcastle disease virus isolated from outbreaks in Egypt during 2006. Virology Journal, 8: 237.

Mayo, M.A. (2002): Names of viruses and virus species - an editorial note. Archives of Virology, 147(7): 1463-1464.

Nabila, O.; Sultan, S.; Ahmed, I.A.; Ibrahim, R.S. and Sabra, M. (2014): Isolation and Pathotyping of Newcastle Disease Viruses from Field Outbreaks Among chickens in the Southern Part of Egypt 2011 -2012. Global Veterinaria 12 (2): 237-243.

OIE, (2012): Newcastle disease. Chapter 2.3.14. OlE Manual of Standards for Diagnostic Tests and Vaccines, NB: Version adopted by the World Assembly of Delegates of the OIE in May 2012. http://www.oie.int/ fileadmin/ Home/eng/Health_standards/tahm/2.03.14_ NEWCASTLE_DIS.pdf

Ogasawara, T.; Gotoh, B.; Suzuki, H.; Asaka, J.; Shimokata, K.; Rott, R. and Nagai, Y. (1992): Expression of factor $\mathrm{X}$ and its significance for the determination of paramyxovirus tropism in the chicken embryo. The EMBO journal 11: 467-472

Panda, A.; Huang, Z.; Elankumaran, S.; Rockemann, D.D. and Samal, S.K. (2004): Role of fusion protein cleavage site in the virulence of Newcastle disease virus. Microbial pathogenesis, 36 (1): 1-10.
Pedersen, J.C.; Senne, D.A.; Woolcock, P.R.; Kinde, H.; King, D.J.; Wise, M.G.; Panigrahy, B. and Seal, B.S. (2004): Phylogenetic Relationships among Virulent Newcastle Disease Virus Isolates from the 2002-2003 Outbreak in California and Other Recent Outbreaks in North America. Journal of Clinical Microbiology, 42: 2329-2334.

Saitou, N. and Nei, M. (1987): The neighbor-joining method: a new method for reconstructing phylogenetic trees. Molecular Biology and Evolution 4: 406-425.

Steward, M.; Vipond, I.B.; Millar, N.S. and Emmerson, P.T. (1993): RNA editing in Newcastle disease virus. Journal of General Virology, 74 (12): 2539-2547.

Tamura, K.; Peterson, D.; Peterson, N.; Stecher, G. and Nei, M., Kumar, S. (2011): MEGA5: molecular evolutionary genetics analysis using maximum likelihood, evolutionary distance, and maximum parsimony methods. Molecular Biology Evolution, 28(10): 2731-2739.

Umali, D.V.; Ito, H.; Suzuki, T.; Shirota, K.; Katoh, H. and Ito, T. (2013): Molecular epidemiology of Newcastle disease virus isolates from vaccinated commercial poultry farms in nonepidemic areas of Japan. Virology Journal 10: 330.

Wehmann, E.; Czegledi, A.; Werner, O.; Kaleta, E.F. and Lomniczi, B. (2003a): Occurrence of genotypes IV, V, VI and VIIa in Newcastle disease outbreaks in Germany between 1939 and 1995. Avian Pathology, 32, 157-163.

Wehman, E.; Ujvari, D.; Mazija, H.; Velhner, M.; Ciglar-Grozdanic, I.; Savic, V.; Jermolenko, G.; Cac, Z.; Prukner-Radovcic, E. and Lomniczi, B. (2003b): Genetic analysis of Newcastle disease virus strains isolated in Bosnia- Herzegovina, Croatia, Slovenia and Yugoslavia, reveals the presence of only a single genotype, V, between 1979 and 2002. Veterinary Microbiology, 94, 269-281.

Westover, K.M. and Hughes, A.L. (2001): Molecular evolution of viral fusion and matrix protein genes and phylogenetic relationships among paramyxoviridae. Molecular phylogenetics and evolution, 21 (1): 128- 134. 


\section{توصيف النشوء والتطور الجينى لفيروسات مرض النيوكاسل شديدة الضراوة المعزولة من في النفوق الحلقى بين دجاج التسمين المحصن في جنوب مصر الفر}

سراج اللين سلطان ، نبيلة عثمان ، أحمد ابراهيم أحدد ، رجب سبي ابراهيم ، محمود صبره

E-mail: seaas@lycos.com. $\quad$ Assiut University Email: www.aun.edu.eg

تم عزل rع عترة من فيروس مرض النيوكاسل من العينات المأخوذة من الدجاج خلال حدوث النفوق الحقلى بين مزارع دجاج

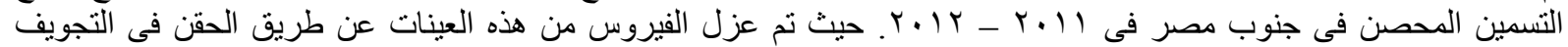

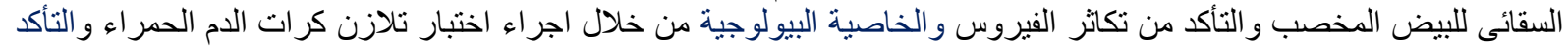

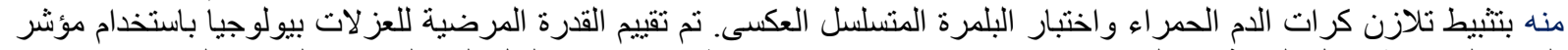

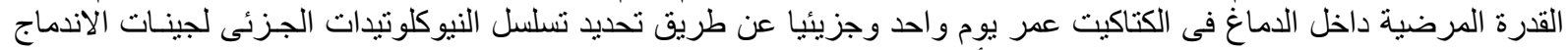

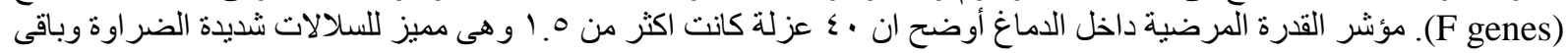

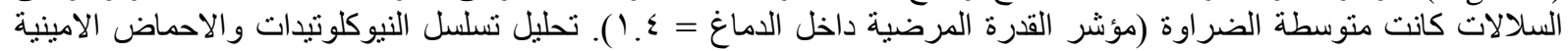

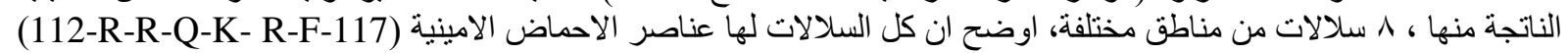

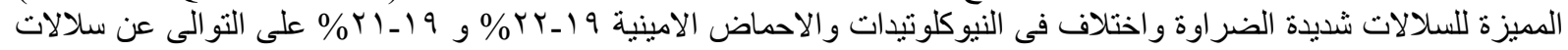

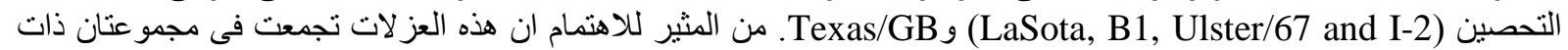

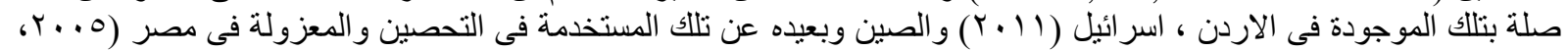

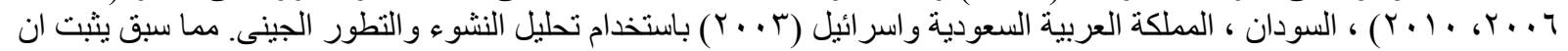

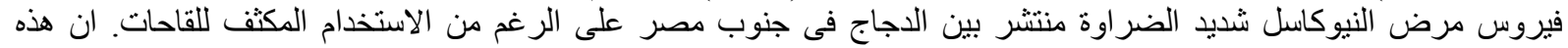

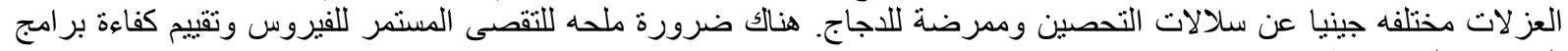
التحصين المستخدمة. 